\title{
„Śpiewajcie Panu..." (Ps 9, 12) \\ Słowo Towarzystwa Biblijnego w Polsce na Ekumeniczne Święto Biblii 2004
}

Pismo Święte na różne sposoby przybliża nas do Boga. Daje nam również wzory modlitw i hymnów. Oprócz najwspanialszej Modlitwy Pańskiej, której sam Zbawiciel nauczył apostołów, mamy w Biblii modlitwy wypo- 
wiadane i hymny śpiewane przez patriarchów, proroków, samego Jezusa Chrystusa, Jego matkę oraz inne postacie biblijne.

Najczęściej używanymi we współczesnych Kościołach chrześcijańskich pieśniami i tekstami modlitewnymi zaczerpniętymi z Pisma Świętego są Psalmy. Zmieniał się świat, ale ich słowa odzwierciedlały i do dziś odzwierciedlają stany duszy czcicieli Boga Prawdziwego. Można słowami Psalmów wzywać świat do chwalenia Boga: „Chwalcie Pana, wszystkie narody...” (Ps 117, 1); można wypowiedzieć radość i podziękowanie Bogu za łaski otrzymane zbiorowo: „Gdy Pan odmienił losy Syjonu, byliśmy jak we śnie...” (Ps 126, 1) lub indywidualnie: „Kiedy Ciebie wzywałem, Ty mnie wysłuchałeś...” (Ps 138, 3); można w tych słowach znaleźć pewność w niepewności: „Pan jest moim pasterzem i nie brak mi niczego...” (Ps 23, 1); siłę do przetrwania, gdy szczególnie ciężko na duszy: „Ratuj mnie, Boże, bo woda już sięga mojej szyi!" (Ps 69, 2); można umocnić się w wierności: „Jeśli zapomnę cię, Jeruzalem, niech uschnie moja prawica!” (Ps 137, 5); można wypowiedzieć jęk duszy, gdy na żadną już ziemską pociechę liczyć nie można: „Ja zaś jestem robakiem, nie człowiekiem, pośmiewiskiem ludzi...” (Ps 22, 7). Każda sytuacja człowieka: czystego sercem czy przygniecionego ciężarem winy, radosnego czy smutnego, znajdzie odbicie w którymś ze 150 Psalmów i każdy Psalm odpowiada określonej sytuacji, w której może się znaleźć wierzący.

Jezus Chrystus, nasz Zbawiciel, wezwał nas do kroczenia Jego śladami, do naśladowania Go. W Ewangeliach często odnajdujemy cytaty z Psalmów lub ich parafrazy: poczynając od chrztu Jezusa w Jordanie, kiedy rozlega się głos: „Ty jesteś Moim umiłowanym Synem...” (Łk 3, 22), będący echem Psalmu 2, 7, aż po słowa przed śmiercią na Krzyżu: „w Twoje ręce powierzam Mojego ducha" (Łk 23, 46). Księga Psalmów jest więc bardzo pomocna do głębszego zrozumienia przesłania ewangelicznego. Nie trzeba być teologiem ani znać historycznego tła poszczególnych Psalmów, aby odczuć ich nastrój, aby je zrozumieć.

Przesłanie Psalmów nie straciło nic ze swojej aktualności. Również i my dzisiaj, pomni na zachętę Apostoła Pawła z Listu do Efezjan 5, 19: „Mówcie do siebie psalmami, hymnami i pieśniami natchnionymi. Śpiewajcie i grajcie waszym sercem Panu...", staramy się żyć treścią i słowami Psalmów, czego wyrazem jest tegoroczne hasło Ekumenicznych Dni Biblijnych: Śpiewajcie Panu! 